\title{
Standardization of cut size and pre-drying time of beef to mainstream pastoral processing in Kenya's meat industry
}

\author{
Josphat Njenga Gichure*, Catherine Nkirote Kunyanga and Jasper K. Imungi
}

\begin{abstract}
Deep-fried and sun-dried meat products represent a large part of the traditional meat products from pastoral regions of sub-Saharan Africa. However, unlike the sun-dried products, deep-fried products are not properly mainstreamed into the meat industry due to lack of product standardization, especially in terms of the size of cut and product quality. This study was designed to standardize the cut and pre-drying time with a view to improving the product quality at processing. Three sets of beef chunks from the silverside portion of a mature Borana bull was cut into sizes 10, 15 and $20 \mathrm{~mm}$. Each set was then pre-dried in a thermostatically controlled air oven at $40{ }^{\circ} \mathrm{C}$ each for 0,60 and $120 \mathrm{~min}$ then deep-fried in palm oil at $170{ }^{\circ} \mathrm{C}$ for $10 \mathrm{~min}$. The products were subjected to chemical analysis based on AOAC methods and sensory analysis based on a seven-point hedonic rating scale. Results show that the products had moisture contents between $14.1 \%$ and $19.4 \%$, protein between $52.1 \%$ and $66.5 \%$, lipids between $10.8 \%$ and $15.4 \%$ and energy between 329.7 and $404.2 \mathrm{kcal} / 100 \mathrm{~g}$. Peroxide values were within acceptable limits and ranged between 0.5 and $3.7 \mathrm{mEq} / \mathrm{kg}$. Sensory evaluation showed that the 20-mm cuts without predrying had significantly the highest scores of colour, appearance, oiliness and size acceptability $(P \leq 0.05)$. On the other hand, the 15-mm cuts pre-dried for 120 min had significantly the highest protein and energy contents and significantly the lowest moisture, fat and peroxide values. The study concludes that in terms of nutritional quality, the 15-mm cut, pre-dried for 120 min, would be most suited for commercialization while, if the decision was to be based on sensory attributes, the 20-mm chunks that have not been pre-dried would be the best.
\end{abstract}

Keywords: Deep-fried, Pre-drying, Chunk size, Pastoral meats, Quality sensory acceptability

\section{Introduction}

Sub-Saharan Africa has an estimated 20 million pastoralists who depend largely on livestock and livestock products for income and food (Wellard-Dyer 2012). In Kenya, there are approximately 4 million pastoralists (Kirkbride and Grahn 2008) with an estimated livestock worth of US\$ 800 million per year (Lindqvist and Verba 2009). Population-wise, the Somali, Turkana and Maasai are the main pastoral communities in Kenya (KNBS 2009). The distribution of these communities is shown in Figure 1.

Processing and preservation of meat by pastoralists is done locally in the villages, on demand, mostly by women who rely on rudimentary technologies. The meat

\footnotetext{
* Correspondence: josphatnjengag@gmail.com

Department of Food Science, Nutrition and Technology, University of Nairobi, P.O. Box 29053-00625, Kangemi, Kenya
}

does not find its way to the formal market because of the challenges of difficulties in package handling and unstandardized, unoptimized quality in processing and storage. The processing is mainly based on indigenous knowledge and the packaging lacks the finesse and the attractiveness of the modern meat package. The size of the cut varies extensively, between and within communities, even for the same product. The packaging used moreover may expose the products to vagaries of the weather, increasing the susceptibility to autoxidation of the fat that the product is abundantly associated with. The packaging used for these products has been demonstrated in our earlier publication (Gichure et al. 2015). Currently, less than $5 \%$ of these products are marketed, mainly in the informal markets within the communities, while the rest is consumed at home. The products are not able to surmount the restrictions of the formal 


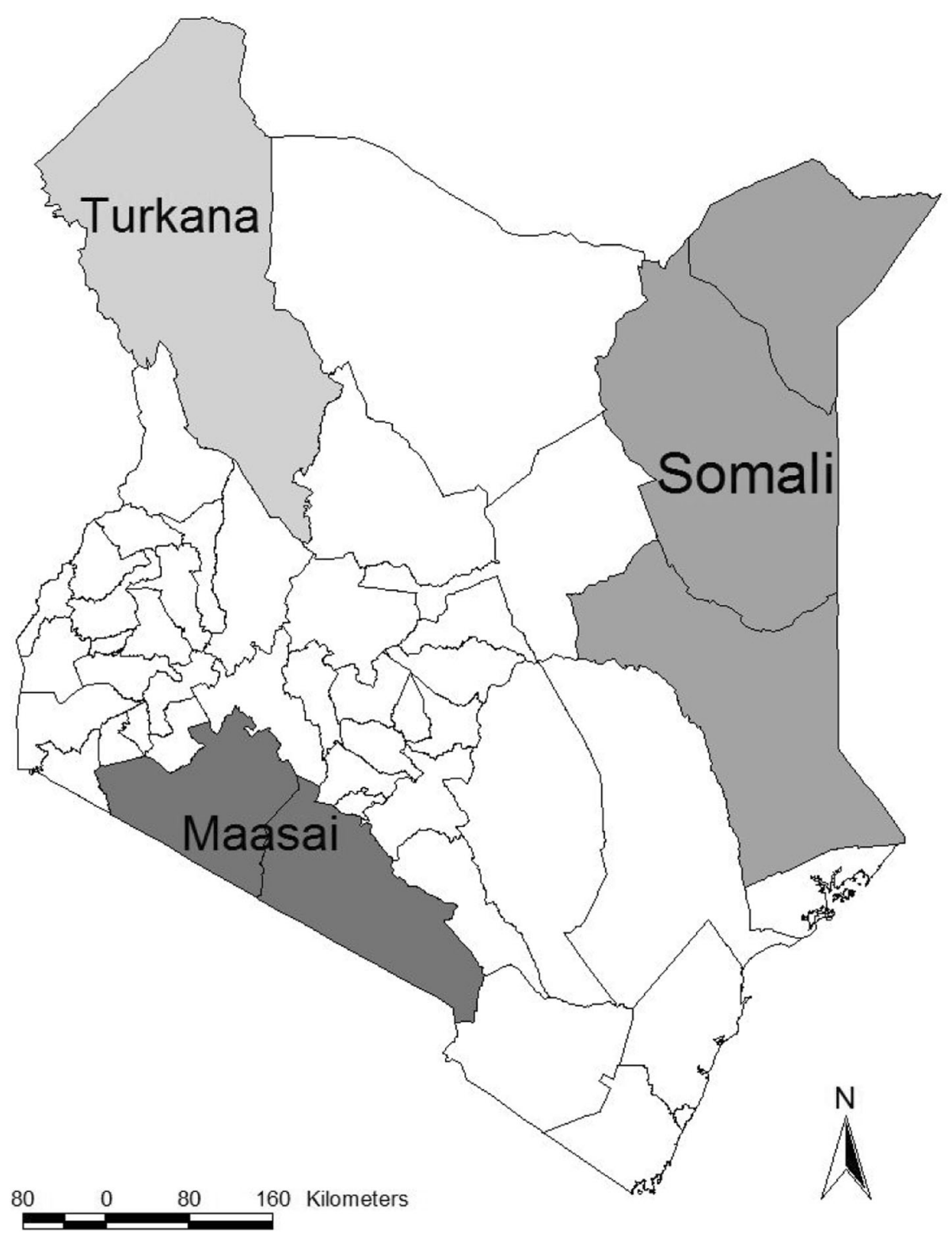

Figure 1 Map of Kenya showing main counties with pastoral communities

market due to various limitations already described (Gichure et al. 2016). In these communities, women rarely own resources, may have less education and cannot access modern infrastructure. This additionally limits their participation in the formal meat products value chain. Previous research on consumer willingness to pay for pastoral meats indicate that finely chopped meat that is tender is most preferred (Wanyoike et al. 2009).

An earlier study reported that the most popular methods of processing and preservation in the pastoral regions of sub-Saharan Africa are deep-frying and sun-drying (Gichure et al. 2014). These methods are considered part of traditional heritage in provision of high energy and protein diets (Lokuruka 2006). In the past decade, studies have been conducted on optimization of the quality traits of these products, but most of the studies have been limited to sundried products. However, as earlier stated, this practice only exists in the rural areas. In sub-Saharan Africa, pastoralists cut lean meat into thin strips, which are exposed to direct sunlight for drying. Depending on the community, the stripes may be marinated, salted or even grilled during the process while drying may take up to five days (Fonkem et al. 2010). In the last two decades, solar driers are increasingly replacing sun-drying as they improve quality 
and safety of dried products, in addition to significantly reducing the drying time.

Globalization and urbanization have introduced deepfried poultry and fish products with considerable success in urban centres over the recent decades. This would indicate a possible opportunity for deep-fried beef, goat and camel snacks which are traditionally processed and consumed in the rural areas of the pastoral regions, opening an opportunity for them to be mainstreamed into the commercial meat chains. This would in turn boost income generation by the pastoral communities, especially by the women who are the main processors.

Deep-frying is considered more of a cooking and dehydration process in which the frying media, the oil, attains $160{ }^{\circ} \mathrm{C}$ to $180{ }^{\circ} \mathrm{C}$. Deep-frying involves simultaneous heat and mass transfer processes (Sosa-Morales et al. 2006). These processes result in extensive changes in product appearance and physical properties, changes which are dependent on the time-temperature and the size of meat chunks (Sosa-Morales et al. 2006; Ziaiifar et al. 2008). During frying, protein are denatured, water vaporized and a crust formed on the product surface; hence, deep-fried snacks have characteristic flavour, texture, cooking effect and satiety as reported by Colmenero et al. (2003) and Acebron and Dopico (2000). The flavour, colour, texture and appearance of deep-fried meats result mainly from protein-carbohydrate interactive reactions (Dobarganes et al. 2000; Choe and Min 2007). Deep-frying by pastoralists is often preceded by pre-drying in the sun to cut down on the moisture content and therefore reduce the oil damage during frying.

Animal fats have been used as frying medium for a long time by pastoralists; however, concerns by urban consumers about cholesterol levels in food and increasing demand for convenient 'snack-like' products have prompted a shift to the use of vegetable oils as frying medium (Gichure et al. 2014). In particular, there is use of saturated vegetable oils which are more thermally stable, have better heat transfer coefficient, are less susceptible to oxidation and are cheaper than unsaturated vegetable oils (Gichure et al. 2015; Ziaiifar et al. 2008). From this review, the study used palm oil as the frying media to capitalize on its high saturated fatty acid content, hence better heat transfer coefficient.

Hydrolysis, oxidation and polymerization may occur during the deep-frying process, and these influence the sensory and chemical qualities of the product (Choe and Min 2007). Hydrolysis and oxidation may cause production of free fatty acids and hydroperoxides which are unstable and may break down further into various compounds which consequently produce off-flavours, leading to a stale, rancid flavour in foods (Angelo 1992). The residual fat in the final products increases susceptibility to oxidative and hydrolytic deterioration during storage.

This study was designed to standardize the size of cut and pre-drying time with a view to developing the most acceptable product quality with regard to physicochemical characteristics and sensory acceptability. This would enable product mainstreaming into the formal market for greater income generation by pastoral communities from their livestock production.

\section{Methods}

\section{Product processing}

Six kilogrammes of lean steak was obtained from the silverside of a 36-month-old Borana bull, slaughtered in a local abattoir in Nairobi. The steak was divided into three chunks of approximately $2 \mathrm{~kg}$ each. The three chunks were each cut into approximately 10-, 15- and 20-mm cubical chunks, then laid on stainless steel perforated trays which were placed in a pre-heated thermostatically controlled cabinet dryer (Innotech, model HT 4, Ingenieursgesellschaft $\mathrm{mbH}$, Germany). The three batches were then pre-dried at $40{ }^{\circ} \mathrm{C}$ for 0,60 and 120 $\mathrm{min}$. The pre-drying environment was designed to simulate the prevailing environmental atmosphere conditions in the Kenyan pastoral regions during the dry season. On average, temperatures in the dry season reach between $30^{\circ} \mathrm{C}$ and $35^{\circ} \mathrm{C}$ and a simple solar drier could be used to concentrate this temperature to a minimum of $40{ }^{\circ} \mathrm{C}$.

From each batch of pre-dried chunks, three samples of approximately $500 \mathrm{~g}$ each were taken and deep-fried at $170{ }^{\circ} \mathrm{C}$ in palm oil using a thermostatically controlled electric fryer (Caterina, model EF101CT/109, China) until the chunks developed a red-brown colour. After deep-frying, excess oil was decanted and the meat chunks placed on a stainless steel sieve for $120 \mathrm{~s}$ to drain off the excess oil. The chunks were then filled into amber glass jars, which were immediately closed with airtight metallic lids. This process is as shown in Figure 2.

\section{Chemical analyses}

Immediately after frying, a sample from each frying was taken and analysed for nutritional composition based on standard proximate techniques. On this, moisture, proteins, lipids, crude fibre, total ash and soluble carbohydrates were analysed by AOAC methods (AOAC 2005). Moisture was determined in a thermostatically controlled air oven by drying about $5 \mathrm{~g}$ sample accurately weighed in a porcelain crucible at $105{ }^{\circ} \mathrm{C}$ to constant weight. Soluble carbohydrates were calculated as a difference. Pearson's (1976) formula was used to calculate the energy values from proteins, lipids and soluble carbohydrates using appropriate factors. Peroxide value was 


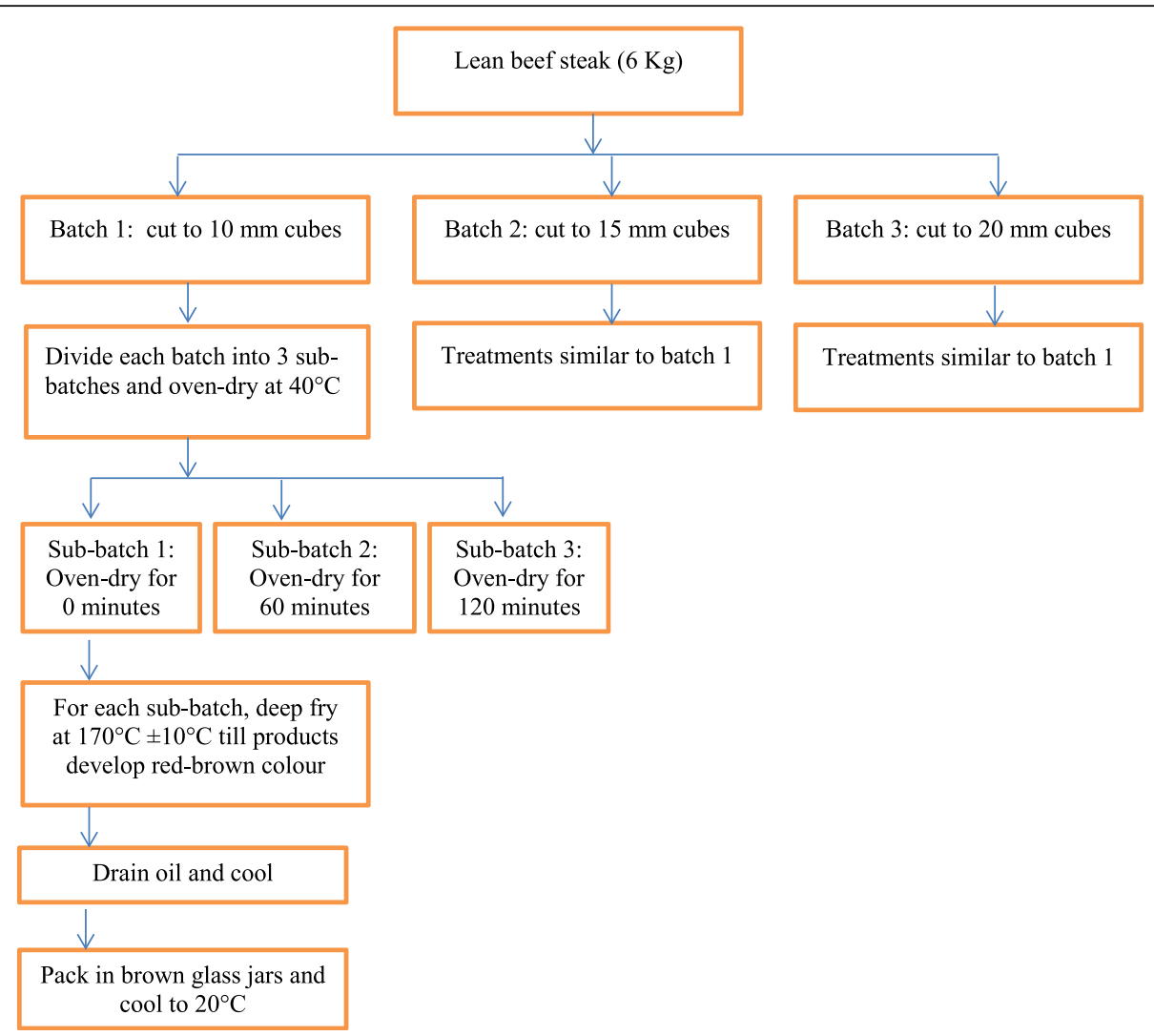

Figure 2 Deep-frying process flow diagram of meat chunks

determined using AOAC methods (AOCS 1993) and was expressed as milliequivalents $(\mathrm{mEq})$ of active oxygen per $\mathrm{kg}$ of product.

\section{Sensory evaluation}

For the final products, colour, appearance, ease of scooping, oiliness, size of chunks, aroma, taste, chewiness and overall acceptability were assessed using 11 trained panellists based on the methods of Elortondo et al. (2007) and Etaio et al. (2013), which are based on ISO 8587:2006 regulations. Random digits were used to code the samples for identification, and the panellists were required to evaluate all attributes for each sample before receiving the next sample. Sample order was randomized to minimize bias due to positional effects. Water was provided, and where panellists were required to taste the samples, they were asked to expectorate and rinse their mouths after each sample. The sensory evaluation room was under similar light intensity, colour, odour and texture; thus, final scores for the products are comparable to each other. The panellists were requested to evaluate the same samples in three sessions on the same day, that is, at 10:00 a.m., 12:00 p.m. and 3:00 p.m. Sample order was randomized across the sessions to minimize bias due to positional effects. After the three sensory sessions, the sensory scores were averaged for each panellist and the means for the replicated sessions obtained. The panellists evaluated acceptability of the products based on sensory attributes using a seven-point hedonic scale where 7 was like very much, 6 was like moderately, 5 was like slightly, 4 was neither like nor dislike, 3 was dislike slightly, 2 was dislike moderately while 1 was dislike extremely. Cronbach's alpha was used to measure the internal consistency of the data collected using the Likert scale.

\section{Statistical analysis}

This experiment was designed as a split-plot, with three separate replications. Genstat 15 (for Windows) was used for statistical analysis. Analysis of variance (ANOVA) was used to compare effects of chunk size and pre-drying time on the chemical and sensory attributes. Duncan's multiple range tests at $P \leq 0.05$ was used to compare the least significant differences of the means.

\section{Results and discussion}

Chemical composition of raw and pre-dried beef chunks The chemical composition of raw and pre-dried beef chunks is shown in Table 1. 
Table 1 Chemical composition of pre-dried beef chunks

\begin{tabular}{llllllllr}
\hline $\begin{array}{l}\text { Size of chunks } \\
(\mathrm{mm})\end{array}$ & $\begin{array}{l}\text { Pre-drying time } \\
(\mathrm{min})\end{array}$ & Moisture (\%) & Lipids (\%) & Protein (\%) & Fibre (\%) & Total ash (\%) & Soluble carbohydrates (\%) & Energy kcal/100 g \\
\hline 10 & 0 & $78.7 \pm 6.5 \mathrm{~b}$ & $1.9 \pm 0.1 \mathrm{c}$ & $18.5 \pm 3.5 \mathrm{a}$ & $0.1 \pm 0.1 \mathrm{a}$ & $0.6 \pm 0.1 \mathrm{a}$ & $0.1 \pm 0.0 \mathrm{a}$ & $91.8 \pm 7.9 \mathrm{a}$ \\
10 & 60 & $77.6 \pm 7.6 \mathrm{ab}$ & $1.3 \pm 0.7 \mathrm{ab}$ & $19.9 \pm 4.4 \mathrm{a}$ & $0.1 \pm 0.1 \mathrm{a}$ & $1.0 \pm 0.7 \mathrm{a}$ & $0.1 \pm 0.1 \mathrm{a}$ & $91.4 \pm 9.1 \mathrm{a}$ \\
10 & 120 & $74.2 \pm 9.8 \mathrm{a}$ & $1.2 \pm 0.7 \mathrm{a}$ & $21.9 \pm 3.9 \mathrm{a}$ & $0.2 \pm 0.1 \mathrm{a}$ & $1.2 \pm 0.2 \mathrm{a}$ & $1.3 \pm 0.6 \mathrm{~b}$ & $103.6 \pm 8.8 \mathrm{a}$ \\
15 & 0 & $78.7 \pm 6.5 \mathrm{~b}$ & $1.9 \pm 0.2 \mathrm{c}$ & $18.5 \pm 3.5 \mathrm{a}$ & $0.1 \pm 0.1 \mathrm{a}$ & $0.6 \pm 0.1 \mathrm{a}$ & $0.1 \pm 0.1 \mathrm{a}$ & $91.8 \pm 7.9 \mathrm{a}$ \\
15 & 60 & $76.3 \pm 6.0 \mathrm{ab}$ & $2.1 \pm 0.4 \mathrm{~d}$ & $19.5 \pm 3.9 \mathrm{a}$ & $0.2 \pm 0.1 \mathrm{a}$ & $1.0 \pm 0.1 \mathrm{a}$ & $1.0 \pm 0.3 \mathrm{~b}$ & $101.0 \pm 26.0 \mathrm{a}$ \\
15 & 120 & $75.9 \pm 5.8 \mathrm{ab}$ & $1.3 \pm 1.0 \mathrm{ab}$ & $20.7 \pm 4.2 \mathrm{a}$ & $0.1 \pm 0.1 \mathrm{a}$ & $1.1 \pm 0.5 \mathrm{a}$ & $1.0 \pm 0.1 \mathrm{~b}$ & $105.8 \pm 8.8 \mathrm{a}$ \\
20 & 0 & $78.7 \pm 6.5 \mathrm{~b}$ & $1.9 \pm 0.2 \mathrm{c}$ & $18.5 \pm 3.5 \mathrm{a}$ & $0.1 \pm 0.1 \mathrm{a}$ & $0.6 \pm 0.1 \mathrm{a}$ & $0.1 \pm 0.1 \mathrm{a}$ & $91.8 \pm 7.9 \mathrm{a}$ \\
20 & 60 & $77.1 \pm 8.5 \mathrm{ab}$ & $1.4 \pm 0.5 \mathrm{~b}$ & $20.3 \pm 5.0 \mathrm{a}$ & $0.2 \pm 0.1 \mathrm{a}$ & $1.0 \pm 0.3 \mathrm{a}$ & $0.1 \pm 0.1 \mathrm{a}$ & $93.9 \pm 6.2 \mathrm{a}$ \\
20 & 120 & $76.6 \pm 8.5 \mathrm{ab}$ & $1.3 \pm 0.4 \mathrm{ab}$ & $19.9 \pm 4.3 \mathrm{a}$ & $0.2 \pm 0.1 \mathrm{a}$ & $1.1 \pm 0.1 \mathrm{a}$ & $1.0 \pm 0.4 \mathrm{~b}$ & $95.1 \pm 13.3 \mathrm{a}$ \\
\hline
\end{tabular}

Mean \pm standard deviation ( $N=3$ replicates). Means followed by the same letter are not significantly different from each other $(P<0.05)$

Pre-drying reduced the water content significantly within the cuts for the drying times tested $(P \leq 0.05)$. The percentage reduction in moisture content after drying decreased with increase in the size of the chunks, that is, from $4.5 \%$ in $10-\mathrm{mm}$ cuts to $1.1 \%$ in 20 -mm cuts. This resulted from the decrease in the surface area to volume ratio and the increased distance which the water had to traverse from the inner to the surface. Results also indicate a considerable loss in lipid content during pre-drying which was attributed to melting abstraction from the tissues and intramuscular fat. The protein, fibre and total ash showed a non-significant increase after pre-drying which was attributed to the fact that predrying increased the dry matter content of the chunks as moisture is lost.

\section{Chemical composition and peroxide value of deep-fried products}

The chemical composition of the products after the deep-frying is shown in Table 2.

There was a significant decrease in moisture content with increase in pre-drying time $(P \leq 0.05)$. However, unlike in similar research on deep-fried foods, reduction in moisture content did not significantly $(P \leq 0.05)$ translate to increase in lipid content as suggested by Saguy and Dana (2003). Rather, other factors such as chunk size, chemical composition after pre-drying and the amount of oil that can be drained after deep-frying contributed more to the chemical composition of deep-fried beef which was in line with earlier studies (Ziaiifar, et al. 2008; Vitrac et al. 2002). In addition, as reported by Aprajeeta and others (2015), deep-frying brings up the drying kinetics of foods which may have caused the 20-mm chunks to develop mechanical stress and strain equilibrium inside the chunk matrix structure leading to non-uniform shrinkage. This increased porosity and cracking on the food surface, thereby increasing oil absorption and moisture loss in the final products.

Protein and total ash content reported an apparent increase after deep-frying especially for the 10- and 15-mm chunks. Deep-frying extracted the water thereby increasing dry matter of the final products. On a dry matter basis, the reduction in the fibre and

Table 2 Nutritional composition and peroxide values of pre-dried and deep-fried beef chunks

\begin{tabular}{|c|c|c|c|c|c|c|c|c|}
\hline $\begin{array}{l}\text { Size of chunks } \\
(\mathrm{mm})\end{array}$ & $\begin{array}{l}\text { Pre-drying time } \\
\text { (min) }\end{array}$ & Moisture (\%) & Lipids (\%) & Proteins (\%) & Total ash (\%) & $\begin{array}{l}\text { Soluble carbohydrates } \\
\text { (\%) }\end{array}$ & $\begin{array}{l}\text { Energy } \\
\text { (kcal/100 g) }\end{array}$ & $\begin{array}{l}\text { Peroxide value } \\
(\mathrm{mEq} / \mathrm{kg})\end{array}$ \\
\hline 10 & 0 & $15.7 \pm 1.7 b c$ & $15.4 \pm 1.9 \mathrm{e}$ & $65.4 \pm 5.2 \mathrm{de}$ & $3.9 \pm 0.1 \mathrm{a}$ & $1.0 \pm 0.4 \mathrm{a}$ & $404.2 \pm 20.4 d$ & $2.5 \pm 0.1 c$ \\
\hline 10 & 60 & $14.9 \pm 3.6 \mathrm{ab}$ & $14.0 \pm 2.1 \mathrm{~d}$ & $65.1 \pm 6.4 \mathrm{de}$ & $30.8 \pm 0.6 \mathrm{a}$ & $1.0 \pm 0.2 \mathrm{a}$ & $394.9 \pm 36.2 \mathrm{~d}$ & $1.3 \pm 0.7 b$ \\
\hline 10 & 120 & $14.2 \pm 2.3 \mathrm{a}$ & $11.8 \pm 1.2 b$ & $63.7 \pm 5.7 \mathrm{~cd}$ & $3.8 \pm 1.2 \mathrm{a}$ & $4.9 \pm 1.5 \mathrm{~d}$ & $380.8 \pm 18.5 c$ & $1.2 \pm 0.2 b$ \\
\hline 15 & 0 & $17.1 \pm 3.0 \mathrm{~d}$ & $15.0 \pm 2.1 \mathrm{e}$ & $64.0 \pm 6.7$ cde & $3.9 \pm 0.9 \mathrm{a}$ & $2.9 \pm 1.1 \mathrm{c}$ & $375.7 \pm 40.3 b c$ & $1.3 \pm 0.7 b$ \\
\hline 15 & 60 & $16.0 \pm 2.4 c$ & $10.8 \pm 1.7 \mathrm{a}$ & $65.3 \pm 6.0 \mathrm{e}$ & $3.9 \pm 1.0 \mathrm{a}$ & $2.2 \pm 0.3 b c$ & $396.1 \pm 15.1 \mathrm{~d}$ & $0.8 \pm 0.7 \mathrm{ab}$ \\
\hline 15 & 120 & $14.1 \pm 3.6 \mathrm{a}$ & $12.0 \pm 1.5 b$ & $66.5 \pm 9.3 \mathrm{e}$ & $3.9 \pm 1.4 \mathrm{a}$ & $0.4 \pm 0.1 \mathrm{a}$ & $402.1 \pm 29.6 \mathrm{~d}$ & $0.5 \pm 0.1 \mathrm{a}$ \\
\hline 20 & 0 & $19.4 \pm 5.5 \mathrm{e}$ & $12.6 \pm 3.9 b c$ & $52.1 \pm 6.5 \mathrm{a}$ & $3.8 \pm 2.0 \mathrm{a}$ & $2.0 \pm 0.6 b$ & $329.7 \pm 22.9 \mathrm{a}$ & $3.7 \pm 1.8 \mathrm{~d}$ \\
\hline 20 & 60 & $18.8 \pm 3.7 \mathrm{e}$ & $13.1 \pm 2.0 \mathrm{C}$ & $60.2 \pm 4.2 b$ & $3.8 \pm 1.0 \mathrm{a}$ & $2.0 \pm 0.8 b$ & $367.9 \pm 15.2 b$ & $2.6 \pm 0.5 c$ \\
\hline 20 & 120 & $14.6 \pm 3.1 \mathrm{a}$ & $14.1 \pm 2.0 \mathrm{~d}$ & $62.7 \pm 7.7 c$ & $3.7 \pm 0.4 \mathrm{a}$ & $0.5 \pm 0.6 \mathrm{a}$ & $379.9 \pm 43.8 c$ & $3.4 \pm 2.8 d$ \\
\hline
\end{tabular}

Mean \pm standard deviation ( $N=3$ replicates). Means followed by the same letter are not significantly different from each other $(P<0.05)$ 
soluble carbohydrate contents after deep-frying points out their possible decomposition at $170{ }^{\circ} \mathrm{C}$. The fibre and soluble carbohydrates were further reduced as they take part in carbohydrate-protein interactive chemical reactions, mainly the Maillard reactions. The observed data do not bring out any particular trend in carbohydrate reduction signifying that these reactions use up the available carbohydrates.

Previous research by Dana and Saguy (2006) show that pre-drying prior to deep-frying reduces the time required for deep-fry, reduces the fat/oil absorption of the products and reduces the rate of hydrolyses of deepfrying oil. In this study, oven-drying was done for two hours to mimic sun-drying in pastoral regions. Placing products on stainless steel sieves immediately after deep-frying to drain the deep-frying oil considerably reduced the lipid content of the products. Other studies have shown that draining the frying media immediately after deep-frying and before cooling considerably decreases the rate of oil reabsorption (Dana and Saguy 2006). Similarly, in an earlier similar study, we reported that deep-fried beef chunks cooled in deep-frying oil have fat content of $15.4 \%$ to $37.9 \%$ (Gichure et al. 2016) and the current results show a considerable reduction when oil is drained from products immediately after deep-frying.

Moisture loss and fat uptake during deep-frying have been reported to increase the oxidation, hydrolysis and polymerization reactions of the oil (Choe and Min 2007). In this study, peroxide values were used to measure the extent of oxidation during the deep-frying process. Results show that all products were acceptable with regard to peroxide value. Generally, pre-drying time significantly reduced the peroxide values $(P \leq 0.05)$. This brings out the fact that pre-drying reduces moisture and lipids available for the oxidative reactions. Chunk size also significantly contributed to the rate of chemical reactions; $10-\mathrm{mm}$ cubes had higher peroxide values when compared to $15-\mathrm{mm}$ cubes. This points out the fact that larger surface area to volume ratio increases oxidative reactions. The peroxide values decrease to some point and then increase as reactions between lipids, carbohydrates and moisture become more evident as was the case of the larger $(20 \mathrm{~mm})$ chunks.

\section{Sensory characteristics of deep-fried products}

The results of sensory evaluation of the deep-fried products are shown in Table 3 . Internal consistency was within acceptable range as Cronbach's alphas ranged between 0.709 and 0.844 . Based on a sevenpoint Likert scale, the $20-\mathrm{mm}$ cubes that had not been pre-dried were most preferred (overall acceptability score of $5.3 \pm 0.3)$. The products scored highest on ease of scooping $(5.5 \pm 0.5)$, oiliness $(5.4 \pm 0.7)$ and chunk size $(5.4 \pm 0.6)$.

Duncan's multiple range test at 5\% significance level reveals that chunk size and pre-drying had no significant influence on products' sensory qualities apart from colour, appearance, size and chewiness attributes $(P \leq 0.05)$. In addition, all products were acceptable with regard to all sensory attributes except the $10-\mathrm{mm}$ chunks that had not been pre-dried as it scored less than 3.5 on chewiness. Larger chunks (20-mm cubes) were more preferred to smaller chunks (10-mm cubes). In terms of individual attributes, ease of scooping, oiliness, size and aroma were the most preferred attributes. This was in line with previous studies (Adegoke and Falade 2005; Troy and Kerry 2010). This study shows acceptable scores for all attributes apart from texture (chewiness). Fibre, soluble carbohydrate and protein interactive

Table 3 Mean score of the sensory attributes of the products

\begin{tabular}{|c|c|c|c|c|c|c|c|c|c|c|c|}
\hline $\begin{array}{l}\text { Size of cut } \\
(\mathrm{mm})\end{array}$ & $\begin{array}{l}\text { Pre-drying } \\
\text { period (min) }\end{array}$ & Colour & Appearance & $\begin{array}{l}\text { Ease of } \\
\text { scooping }\end{array}$ & Oiliness & Size of cut & Aroma & Taste & Chewiness & $\begin{array}{l}\text { Overall } \\
\text { acceptability }\end{array}$ & $\begin{array}{l}\text { Mean } \\
\text { score }\end{array}$ \\
\hline 10 & 0 & $4.5 \pm 0.5 a$ & $4.5 \pm 0.3 a$ & $5.9 \pm 0.2 \mathrm{a}$ & $5.8 \pm 0.4 a$ & $5.3 \pm 0.5 a b$ & $4.9 \pm 1.0 \mathrm{a}$ & $4.9 \pm 0.3 a$ & $3.3 \pm 0.5 a$ & $4.6 \pm 0.3 \mathrm{a}$ & $4.9 \pm 0.2$ \\
\hline 10 & 60 & $4.3 \pm 0.3 a$ & $4.3 \pm 0.5 a$ & $5.9 \pm 0.1 \mathrm{a}$ & $5.7 \pm 0.4 a$ & $5.1 \pm 0.2 \mathrm{ab}$ & $4.8 \pm 0.7 \mathrm{a}$ & $4.9 \pm 0.4 a$ & $3.8 \pm 0.9 a b$ & $4.6 \pm 0.6 a$ & $4.8 \pm 0.2$ \\
\hline 10 & 120 & $4.3 \pm 0.1 \mathrm{a}$ & $3.9 \pm 0.2 \mathrm{a}$ & $5.5 \pm 0.5 \mathrm{a}$ & $5.5 \pm 0.8 \mathrm{a}$ & $4.7 \pm 0.1 \mathrm{a}$ & $4.7 \pm 0.4 \mathrm{a}$ & $4.9 \pm 0.8 \mathrm{a}$ & $3.9 \pm 1.1 \mathrm{ab}$ & $4.7 \pm 0.3 \mathrm{a}$ & $4.7 \pm 0.3$ \\
\hline 15 & 0 & $4.9 \pm 0.3 a$ & $4.7 \pm 0.1 \mathrm{ab}$ & $5.3 \pm 0.2 \mathrm{a}$ & $5.2 \pm 0.6 \mathrm{a}$ & $5.0 \pm 0.5 \mathrm{ab}$ & $5.0 \pm 0.3 \mathrm{a}$ & $5.2 \pm 0.6 a$ & $4.4 \pm 0.2 b$ & $4.9 \pm 0.5 \mathrm{a}$ & $5.0 \pm 0.5$ \\
\hline 15 & 60 & $4.9 \pm 0.4 \mathrm{a}$ & $4.5 \pm 1.0 \mathrm{a}$ & $5.4 \pm 0.6 \mathrm{a}$ & $5.3 \pm 0.2 \mathrm{a}$ & $5.6 \pm 0.6 \mathrm{ab}$ & $5.1 \pm 0.6 \mathrm{a}$ & $5.2 \pm 0.3 a$ & $4.2 \pm 0.4 a b$ & $4.9 \pm 0.3 \mathrm{a}$ & $5.0 \pm 0.3$ \\
\hline 15 & 120 & $4.8 \pm 0.3 a$ & $4.5 \pm 0.2 \mathrm{a}$ & $5.7 \pm 0.3 \mathrm{a}$ & $5.3 \pm 0.1 \mathrm{a}$ & $5.8 \pm 0.3 \mathrm{ab}$ & $5.1 \pm 0.4 a$ & $5.0 \pm 0.7 \mathrm{a}$ & $3.7 \pm 0.6 \mathrm{ab}$ & $4.8 \pm 0.4 \mathrm{a}$ & $5.0 \pm 0.1$ \\
\hline 20 & 0 & $6.1 \pm 0.6 b$ & $5.8 \pm 0.1 b$ & $5.5 \pm 0.4 \mathrm{a}$ & $5.7 \pm 0.3 a$ & $6.3 \pm 0.3 b$ & $5.0 \pm 0.4 \mathrm{a}$ & $4.9 \pm 0.3 \mathrm{a}$ & $3.5 \pm 0.5 \mathrm{a}$ & $4.6 \pm 0.3 \mathrm{a}$ & $5.3 \pm 0.3$ \\
\hline 20 & 60 & $5.1 \pm 0.3 \mathrm{ab}$ & $5.7 \pm 0.3 b$ & $5.3 \pm 0.3 a$ & $5.4 \pm 0.1 \mathrm{a}$ & $5.6 \pm 0.3 a b$ & $5.4 \pm 0.1 \mathrm{a}$ & $4.7 \pm 0.3 \mathrm{a}$ & $4.3 \pm 0.3 b$ & $4.7 \pm 0.2 \mathrm{a}$ & $5.1 \pm 0.1$ \\
\hline 20 & 120 & $5.1 \pm 0.1 \mathrm{ab}$ & $5.1 \pm 0.2 \mathrm{ab}$ & $5.3 \pm 0.2 \mathrm{a}$ & $5.1 \pm 0.3 a$ & $5.4 \pm 0.3 a b$ & $5.6 \pm 0.2 \mathrm{a}$ & $4.6 \pm 0.4 a$ & $4.6 \pm 0.3 b$ & $4.8 \pm 0.6 \mathrm{a}$ & $5.1 \pm 0.8$ \\
\hline Mean & & $4.9 \pm 0.6$ & $4.8 \pm 0.8$ & $5.5 \pm 0.5$ & $5.4 \pm 0.7$ & $5.4 \pm 0.6$ & $5.1 \pm 0.7$ & $4.9 \pm 0.6$ & $4.0 \pm 0.6$ & $4.7 \pm 0.6$ & \\
\hline
\end{tabular}

Mean \pm SD $(N=3$ replicates). Reliability of the Likert scale (Cronbach's alpha): colour $=0.712$, appearance $=0.709$, ease of scooping $=0.827$, oiliness $=0.719$, size of cuts $=0.751$, aroma $=0.809$, taste $=0.718$, chewiness $=0.844$, overall acceptability $=0.730$. Means followed by the same letter are not significantly different from each other $(P \leq 0.05)$ 
reactions have been associated with sensory attributes, namely colour, appearance and aroma (Dobarganes et al. 2000; Choe and Min 2007). Similarly, results from this study show this relationship between chemical composition of pre-dried chunks and sensory attributes of deep-fried chunks.

\section{Conclusion and recommendation}

The study shows that chunk size and pre-drying were the main factors that contribute to the chemical characteristics of deep-fried beef. Other factors that were identified were chemical composition after pre-drying and the amount of oil-draining after the deep-frying process. On the other hand, pre-drying and increasing the chunk size improved the sensory characteristics. Oxidation which has been reported to be the main cause of chemical spoilage was least in the $15-\mathrm{mm}$ chunks while larger chunks $(20 \mathrm{~mm})$ had higher moisture content while smaller chunks $(10 \mathrm{~mm})$ had more lipids. Fibre, soluble carbohydrate and protein interactive reactions were seen to be associated with colour, appearance and aroma of deep-fried chunks. Pre-drying was seen to improve oiliness, aroma, chewiness and overall acceptability of deepfried beef. Increasing the size of chunks was seen to improve the colour, appearance, aroma, taste, chewiness and overall acceptability.

\section{Acknowledgements \\ The authors are grateful for the financial support of the RELOAD (Reducing Losses Adding Value) Project of the German Federal Ministry of Education and Research (BMBF).}

\section{Authors' contributions}

$J \mathrm{~N}$ : the main author, was involved in the whole process from conception and design, acquisition of the data analysis and interpretation of the data. He was also involved in drafting the manuscript. CNK: made substantial inputs during the research process from conception and design, data collection, analysis and interpretation and the manuscript writing. Being part of the supervision team, CNK approved the final version to be published. JKI: made substantial inputs during the research process from conception and design, data collection, analysis and interpretation and the manuscript writing. Being part of the supervision team, JKl approved the final version to be published. All authors read and approved the final manuscript.

\section{Competing interests}

The authors declare that they have no competing interests. This research was funded by the German Federal Ministry of Education and Research, and the funding organization had no financial and non-financial interest in the research. The funding organization did not influence the output from the research in any way. This article is part of my PhD thesis at the University of Nairobi.

Received: 25 June 2016 Accepted: 15 December 2016

Published online: 13 January 2017

\section{References}

Acebron, L.B., and D.C. Dopico. 2000. The importance of intrinsic and extrinsic cues to expected and experienced quality: An empirical application for beef. Food Quality and Preference 11: 229-238.

Adegoke, G.O., and K.O. Falade. 2005. Quality of meat. Journal of Food, Agriculture and Environment 3: 87-90.

Angelo A.J. 1992. Lipid oxidation in food. In ACS symposium series (USA). American Chemical Society
AOAC (Association of the Official Analytical Chemists). 2005. Official methods of analysis. Washington DC: AOAC International.

AOCS. 1993. Tentative methods of the American Oil Chemists' Society. Champaign, IL Aprajeeta, J., R. Gopirajah, and C. Anandharamakrishnan. 2015. Shrinkage and porosity effects on heat and mass transfer during potato drying. Journal of Food Engineering 144: 119-128.

Choe, E., and B.D. Min. 2007. Chemistry of deep-fat frying oils. Journal of Food Science 72(5): 77-86.

Colmenero, F.J., A. Serrano, J. Ayo, M.T. Solas, S. Cofrades, and J. Carballo. 2003. Physicochemical and sensory characteristics of restructured beef steak with added walnuts. Meat Science 65(4): 1391-1397.

Dana, D., and I.S. Saguy. 2006. Review: Mechanism of oil uptake during deep-fat frying and the surfactant effect-theory and myth. Advances in Colloid and Interface Science 128: 267-272.

Dobarganes, C., G. Márquez-Ruiz, and J. Velasco. 2000. Interactions between fat and food during deep-frying. European Journal of Lipid Science and Technology 102(8-9): 521-528.

Elortondo, F.P., M. Ojeda, M. Albisu, J. Salmerón, I. Etayo, and M. Molina. 2007. Food quality certification: An approach for the development of accredited sensory evaluation methods. Food Quality and Preference 18(2): 425-439.

Etaio, I., P.F. Gil, M. Ojeda, M. Albisu, J. Salmerón, and F.P. Elortondo. 2013. Evaluation of sensory quality of calf chops: A new methodological approach. Meat Science 94(1): 105-114.

Fonkem, D.N., V.N. Tanya, and A.L. Ebangi. 2010. Effects of season on the microbiological quality of Kilishi, a traditional Cameroonian dried beef product. Tropicult 28: 10-15.

Gichure, J.N., C.N. Kunyanga, P.M. Mathi, and J.K. Imungi. 2014. The present status of meat processing and preservation in the pastoral regions of Kenya. Food Science and Quality Management 34: 42-50.

Gichure J.N., C.N. Kunyanga, P.M. Mathi, and J.K. Imungi. 2015. Meat preservation technologies in Kenya's pastoral areas with potential for market competitiveness improvement. Paper presented at Conference on Policies for Competitive Smallholder Livestock Production. Gaborone, Botswana, 4-6 March 2015.

Gichure, J.N., C.N. Kunyanga, and J.K. Imungi. 2016. Chemical and sensory evaluation of pastoral meat products. In press.

Kirkbride, M., and R. Grahn. 2008. Survival of the fittest: Pastoralism and climate change in East Africa. Oxfam Policy and Practice: Agriculture, Food and Land 8(3): 174-220.

KNBS 2009. Population and housing census. Kenya National Bureau of Statistics: Nairobi, Kenya: 2010. Available at: http://www.knbs.or.ke/index.php?option=com_ phocadownload\&view=category\&id=109:population-and-housing-census2009\&ltemid=599. Accessed 19 June 2013.

Lindqvist A.K., and T. Verba. 2009. Overview of drylands development communication initiatives in Africa. Chicago. http://pubs.iied.org/pdfs/G02494.pdf.

Lokuruka, M.N. 2006. Meat is the meal and status is by meat: Recognition of rank, wealth, and respect through meat in Turkana culture. Food and Foodways: Explorations in the History and Culture of Human Nourishment 14(3-4): 201-229.

Pearson D. 1976. The chemical analysis of foods (no. ed. 7). Longman Group Ltd.

Saguy, I.S., and D. Dana. 2003. Integrated approach to deep fat frying: Engineering, nutrition, health and consumer aspects. Journal of Food Engineering 56: 143-152.

Sosa-Morales, M.E., R. Orzuna-Espiritu, and J.F. Velez-Ruiz. 2006. Mass, thermal and quality aspects of deep-fat frying of pork meat. Journal of Food Engineering 77: 731-738.

Troy, D.J., and J.P. Kerry. 2010. Consumer perception and the role of science in the meat industry. Meat Science 86: 214-226.

Vitrac, O., D. Dufour, G. Trystram, and A.L. Raoult-Wack. 2002. Characterization of heat and mass transfer during deep-fat frying and its effect on cassava chip quality. Journal of Food Engineering 53: 161-176.

Wanyoike, F., S. Kaitibie, and A.O. Omore. 2009. Can small-scale actors earn higher returns from improved quality and safety of animal products? Unpublished manuscript

Wellard-Dyer K. 2012. Pastoralism in the Horn of Africa: Diverse livelihood pathways. Future Agricultures Consortium Secretariat, University of Sussex, Brighton

Ziaiifar, A.M., N. Achir, F. Courtois, I. Trezzani, and G. Trystram. 2008. Review of mechanisms, conditions, and factors involved in the oil uptake phenomenon during the deep-fat frying process. International Journal of Food Science and Technology 43: 1410-1423. 